\title{
The tale of the fungi of two gardens: non-lichenised fungi of the Botanic Gardens in Glasgow
}

\author{
R. Watling \\ Caledonian Mycological Enterprises, Edinburgh EH4 3HU \\ E-mail: caledonianmyc@blueyonder.co.uk
}

\begin{abstract}
A brief history of the early days of mycology in Scotland is given to act as a starting point from which to view the fungal records made in the gardens at Sandyford and Kelvinside. The former was vacated in 1842 and the garden transferred to the present site at Kelvinside under the authority of the Glasgow City Council. The role of J.F. Klotzsch in generating the earliest records is emphasised and the compilation of fungal records, mainly of macrofungi, until the present day is discussed. A short account of the microfungi is given. A complete list of the fungi recorded from the two gardens is provided.
\end{abstract}

\section{INTRODUCTION - SETTING THE SCENE}

Thomas Hopkirk was a founding father of the Royal Botanic Institution of Glasgow, which was assigned land for a Botanic Garden at Sandyford, then on the western outskirts of the city. He is best known in mycological circles for the inclusion of an account of the fungi of Clydesdale in his Flora Glottiana "that it may prove useful to the Botanical student" (Hopkirk, 1813). It includes 104 fungal names and is the first such account of a local fungal flora to appear in Britain. Before Hopkirk one Clydesdale botanist named a handful of fungi in his History of Rutherglen and East Kilbride (Ure, 1792), including the scarlet cup "Sarcoscypha coccinea" (although the specific taxon is unknown, as a former variety - var. jurana - is now considered to be a distinct species).

Hopkirk was a graduate of the University of Glasgow, becoming an important Glasgow businessman and a friend of William Jackson Hooker when he came to Glasgow to take up the position of Professor of Botany. Hooker had given up microscopic work by then, because, since James Sowerby had died before the completion of his British Flora, it had fallen on Hooker to complete the task. He soon concentrated on the flowering plants, admitting that he knew very little about fungi. He relied heavily on Lightfoot (1777), who paid unusual attention to the fungi (Ramsbottom, 1963). Hooker, although relying partly on Hopkirk as well as Dickson (1785-1801), opted to use A Botanical Arrangement of British Plants (Withering, 1792) for the major part of his work, but decided to base the section on fungi on Persoon (1797). He was assisted in this endeavour by a young student from Germany,
J.F. Klotzsch. Hooker had collected a few specimens, some of which are in the herbarium of the Royal Botanic Gardens, Edinburgh, but Klotzsch set about documenting these as well as gathering fungi from around Glasgow for inclusion in Hooker's herbarium. He also travelled further afield, e.g. to Castle Semple, Renfrewshire, and to the Highlands where he accompanied Hooker. Watling (2016) listed the localities where Klotzsch collected whilst in Scotland. Klotzsch stayed in Glasgow for two years, accumulated a vast collection for Hooker, and introduced the idea of slicing specimens before they were dried for preservation. Following the tradition of the time, these specimens, along with his library and manuscripts, followed Hooker to the Kew Botanical Gardens when he went there as Director in 1841 (Bower, 1901). The Kew fungal material became the basis of the now internationally recognized fungarium at Kew, but some material apparently made its way to at least two places in Scotland, as documented by Watling (2014, 2016). Sadly no specimens collected by Hopkirk have been located. Perhaps the Edinburgh material of Klotzsch was part of an exchange with the Edinburgh-based cryptogamist, R.K. Greville, also a friend of Hooker, although there are no details of a gift or exchange in the documents at the Edinburgh's Royal Botanic Gardens. In the Mycologia Scotica of Stevenson (1879) there are frequent references to Klotzsch when records assigned to Hooker are mentioned. A collection now in the Glasgow Museums Resource Centre contains Klotzsch material gifted by a Capt. Fleming and includes several specimens from Inveraray, Argyll and Bute, and material from Garscube, Glasgow. A collection of Sphaeria (Depazea) unedonicola Klotzsch is referred to by Grove (1935-37), although it apparently lacks Klotzsch's manuscript name. This collection has been discussed by Watling (2014). Hooker's floristic work, including fungi, was completed by M.J. Berkeley and finally appeared as part of both The English Flora of Sir James Edward Smith Vol. 5 and Dr. Hooker's British Flora Vol. 2 (Hooker, 1836). Sadly, after Klotzsch there was a mycological void for about forty years until R.H. Paterson's contributions (see below) and by this time the garden had been moved from Sandyford to Kelvinside (Bower, 1901).

There are records of fungi collected by R.H. Paterson and members of The Andersonian Naturalists of 
Glasgow from Bowling, Helensburgh, Ben Lomond, Ben Vorlich, Luss, Toward and Innellan, as well as Glasgow, including the Kelvinside Botanic Gardens. Paterson and others prepared a list of fungi for the 1876 British Association Handbook for its Glasgow meeting (Paterson, 1876). The handbook contains 34 pages of fungal names in double columns with no information except district. In his account of Scottish mycology Ramsbottom (1963) considers Paterson's appendix to be worthless, although those fungi found in the Sandyford garden are indicated. Nineteen fungi are specifically referred to this garden, including seven microfungi, two rusts, three truffles, two fairy-clubs and four agarics. He included some of Klotzsch's records. Paterson also edited later editions of The Clydesdale Flora (Hennedy, 1878), but in all editions, as in similar floras of the region such as Lee's (1933), the text does not mention fungi. In 1890 T. King is noted as having found chanterelles (Cantharellus cibarius) in the Kelvinside Botanic Gardens, but he is best known for encouraging local cryptogamists and assisting their curation of the Hennedy collections (Stewart, 1901). Paterson corresponded with Greville, being mentioned in A Scottish Cryptogamic Flora (Greville, 1823-28) as was J. Rennie of Glasgow. In Edinburgh there is material collected by R.H. Paterson in M.J. Cooke's herbarium, for instance the small discomycete Hyalinia rubella.

At the turn of the century a list of gasteromycetes collated by R.B. Johnstone was incorporated into The Fauna, Flora and Geology of Clyde Area (Stewart, 1901). Johnstone was treasurer of the Cryptogamic Society of Scotland and in his time added 100 species to the Scottish fungal list, many from the Glasgow area. He was variously Secretary (1891-1913) and President (1917-1918) of The Andersonian Naturalists of Glasgow.

Toward the end of the first decade of the 20th century Daniel Alexander Boyd sat on a subcommittee that prepared a report on the fungi of Clydesdale district for another Glasgow British Association meeting (Anon., 1928). This account added seven new records and had references to the classic collectors of the time such as the Rev. J. Stevenson and Rev. J. Keith. Boyd also wrote an article on fungi for a third British Association Meeting (Boyd, 1928), where he developed ideas on the occurrence of fungi in relation to the physical features of the Clyde area. Boyd was qualified as a Writer to the Signet but never practised and spent his time studying archaeology and natural history, finally taking a particular interest in "stem and leaf fungi" (coelomycetes) and other microscopic entities. He became noted for his many records new to the British Isles and his records and experience were acknowledged in what was until very recently the standard work on these organisms (Grove, 1935-1937). Some of these specimens would have been transferred when the British Museum's collection of fungi went to Kew. Sadly, although some of his specimens are said to have been located in the Kew fungarium, few have survived to voucher the records. A few specimens have been found in the herbaria of Strathclyde and Glasgow Universities (Watling, 1986), which are now incorporated into the Glasgow Museums Resource Centre as the Glasgow University Herbaria. A few others have now been located in the Edinburgh Herbarium. Boyd published many of his finds in The Scottish Naturalist, and these records appeared as appendices to the supplements in Stevenson (1879). R.B. Johnstone (1931) recorded that this was the last contribution made by Boyd, as he died in 1928.

R.H. Johnstone (son of R.B. Johnstone, mentioned above) was a member of the British Mycological Society and selected collecting sites for the 1959 foray based in Glasgow and for the European Mycological Congress held in Glasgow in 1963. The identities of specimens collected on those occasions were confirmed by a range of British mycologists. R.H. Johnstone published notes on Clydesdale fungi in The Glasgow Naturalist (Johnstone, 1946). Specimens belonging to R.H. Johnstone, formally housed at the University of Glasgow, and material from the University of Strathclyde are now located in the Glasgow Museums Resource Centre.

The above historical account provides a background against which the fungi recorded from the Sandyford and Kelvinside gardens can be discussed. It should be mentioned that there is no information on the fungi of the Physic Garden owned by the University of Glasgow, which existed prior to 1817 at the High Street site (Boney, 1986) and which was the forerunner of the Sandyford garden.

\section{THE LARGER FUNGI: SANDYFORD}

All material indicated by Klotzsch to be from the "Botanic Garden" would have come from the Sandyford site and not the present day garden at Kelvinside. Thus there is some discrepancy in the records held by the British Mycological Society, which mix those from the two gardens. Another problem is that when old names were updated to accord with current usage generally no reference was made to the actual specimens, thus providing a potential source of error.

Many of Klotzsch's collections are unlocalised and fungi are described as being "common" or "widespread" with or without accompanying data. Many of these specimens could have originated from the Sandyford garden as the taxa noted would be expected to occur in the grounds of any wooded plot. This also applies to the listings in Paterson (1876), since the designation "common" might include Botanic Garden collections. On the other hand, it is well-documented that whilst in Scotland Klotzsch described several species new to science based on collections from the Sandyford garden. One species is named after Klotzsch's mentor, W.J. Hooker - Agaricus hookeri, placed in the classic texts under Lepiota, although erroneously in Hebeloma by Paterson (1876). It is now known to be the same as Melanophyllum haematospermum, a small, insignificant agaric which generally favours relatively base-rich soils in shrubberies and at wood-margins. Another species 
was named after Hooker's wife, who apparently found it in the garden - Agaricus mariae, a species which was soon transferred to Lepiota but is now known as Echinoderma asperum. It was listed by Paterson (1876). Perhaps one of the most spectacular fungi Klotzsch described was from the glass-houses at the Sandyford garden - the false truffle Hymenangium album, a "reduced" secotiaceous member of the Cortinariales. Nomenclatorially it has had a chequered career, for, although always accepted as a distinct species, it has been moved from one genus to another and even the specific name has been changed (viz. Hymenogaster klotzschi), due to a misinterpretation by the "father of British mycology" - the Very Rev. M.J. Berkeley. It has finally been returned to Klotzsch's original genus. Klotzsch's false truffle is apparently native to the eucalypt forests of Australia and was obviously brought in on the roots of a plant introduction. It has been found in botanic gardens in Edinburgh, Kew and on the continent, always associated with eucalypts. There are two collections in Kew, which are both from the Sandyford garden, one being the isotype.

Another new species was published by Berkeley with reference to Klotzsch, viz. Psilocybe areolata, which represents a form of the weeping widow (Lacrymaria lacrymabunda) possessing a cracked pileus. The basidiospores are distinctive, so allowing placement with certainty in Lacrymaria, but the present author has never, in many years of collecting, found the pileus of L. lacrymabunda cracking. It is possible that the fibrillose velar tissue might have separated on drying to reveal the cuticle below, which, in common with other psathyrelloid agarics, is a cellular hymeniderm; in some species this becomes fissured. This fungus is characterised by soot black gills, which produce strongly ornamented basidiospores with wart like prominences. Its common name - weeping widow comes from the fact that, when growing actively, the gills produce glistening droplets of a watery fluid which contrast with the dark gills, recalling a widow's grief and clothing. Klotzsch did not appreciate the variability of this fungus, since he introduced "Agaricus tabularis" for a collection of the very same taxon, which was also collected in the Sandyford garden. However, another species had previously been named "Agaricus tabularis" (which is now Cortinarius tabularis). The small size exhibited by Klotzsch's collection may show he was right in recognising a separate entity, since it could represent $L$. glareosa, a very close relative of the weeping widow, which is difficult to separate without field data. It grows in disturbed gravelly areas, on construction sites, and at the edges of glacial activity, the last probably being the natural habitat. A surprise amongst the Klotzsch material is Hebeloma radicosum, as it has a rather restricted distribution in Scotland. It was collected in Sandyford in August 1830 and is a particularly interesting record as the fungus has been shown to be intimately connected with the burrows of moles and rodents.

THE LARGER FUNGI: KELVINSIDE

Paterson (1876) listed a few species from what must have been the garden at Kelvinside, viz. Agaricus (now Leucocoprinus) cepistipes, commonly found near habitation on leafy litter, Tricholoma (now Leucoagaricus) meleagris, a species that grows on warmed wood shavings and leaf mould, and Agaricus (now Hebeloma) crustuliniforme, a species also recorded by William Stewart in 1897, along with Lepista (as Tricholoma) sordida. The last might be expected to occur with birch (Betula spp.) in the Kelvinside garden. L. sordida is a fungus of shrubberies, so the presence of this agaric is not surprising. A collection of the closely related field blewit (L. saeva) is very interesting, as this species is a truly grassland agaric; it was discovered in the Kelvinside garden by a member of the general public. Paterson also included in his listings Lepiota acutesquamosa, which must refer to Klotzsch's Agaricus mariae (now Echinoderma asperum), and L. clypeolaria, which has been discussed extensively (Watling, 2014). Other species of fungi mentioned by Paterson (1876) are rather significant and many reflect a history of introduction, e.g. another false truffle, Hydnangium carneum, associated with eucalypts. A record of Hymenogaster muticus contradicts Legon \& Henrici (2005) who consider the species is known only from the type locality near Bristol, U.K. and a recent unsubstantiated record from Tring, U.K. Paterson also recorded the extremely poorly known Galera confertus, originally described from hot-houses. This could well be another introduced species, although the original plate suggests it could be a Conocybe sp. (see Legon \& Henrici, 2005).

In the currently available data-sets of British fungal records, no distinction has been made between the two gardens at Sandyford and Kelvinside. Since the Glasgow garden changed location to the present site, sadly few records exist that can be accurately placed. In 1889 several independent collections of Clavaria tenuipes and $C$. fragilis (both collections in the Edinburgh herbarium) were made in the Kelvinside garden and 100 years later $C$. tenuipes and C. argillacea (now in the Kew fungarium) were collected. Also in the Kew fungarium is a specimen of the bright red Pycnoporus cinnabarinus from the 1800s, which may be assignable to Klotzsch, as he took a particular interest in bracket fungi. There is, however, no further information and it could be the specimen submitted by Paterson to M.C. Cooke at Kew (Anon., 1877). P. cinnabarinus possesses a bright red basidiome and has a continental distribution in Europe, although it is found as far north as North Cape in Norway. It is not found along the western shores of Norway and is rare in the British Isles where the only record supported by material in the Kew fungarium is from Murthly, Scotland in 1913. There are a few unsubstantiated records from England. The Glasgow collection might have had its origin in Europe or even farther afield and was possibly introduced on an exotic substrate at the garden.

There is a vouchered Kelvinside record in the Kew fungarium of the carrot-red truffle Stephanospora caroticolor reported by Stewart (1901) and now at Kew, a rare species originally described from England, 
although it is also known from France, Germany and Switzerland. It is subhypogeous and grows generally under yew (Taxus spp.), although it has been found beneath other conifers. It is easily identified by the bright orange colours, especially when the basidiome is cut open. It is closely related to the resupinate genus Lindtneria based on the morphology of the basidiospores alone.

An undated collection of "Stereum ostrea" is probably a collection of Stereum lobatum (= S. ostrea var. lobatum) that was sent by Paterson to Cooke at Kew for identification. It is a rather unusual curtain fungus, which is widespread in the tropics, especially in the U.S.A. and in southeast Asia, although it is also recorded from several botanic gardens both here and abroad. In Europe it is found on decayed wood in warm tropical glasshouses, again suggesting that it has been introduced. Although larger and more frondose, it is similar to the British S. gausapatum and does not "bleed when scratched".

In the same Kew consignment mentioned above Trichaptum biforme (as Polyporus pergamenus) was noted. This is a widespread polypore in North America and the tropics, which is morphologically similar to our common British T. abietinum, but differs by growing on broad-leaved hosts instead of conifers. These specimens and others sent by Paterson to Cooke were published as a note (Anon., 1877) in which it was commented: "Of course no one would expect these to become distinguished foreigners permanently resident in the country". The split-gill (Schizophyllum commune) was included in the batch for identification, a species which in the past was restricted in its distribution in the U.K., although it was found at Kelvinside by R.H. Johnstone later in 1901. It has spread rapidly throughout Britain since the Second World War and is now not infrequently found on treated straw-bales in storage.

Subsequent records of fungi from the Kelvinside garden are the result of brief visits and are of relatively common species that would fall into Klotzsch and Paterson's categories of "common and widespread" or "common".

At a British Association for the Advancement of Science meeting held in Glasgow in 1904, the beef steak fungus (Fistulina hepatica) was noted by a delegate member whilst on a visit to the Kelvinside garden. In Britain this is a relatively common and widespread bracket fungus, most notably growing on oak (Quercus spp.) and sweet chestnut (Castanea sativa), and it might be expected on a specimen tree at Kelvinside.

The clavarioid fungi deposited in Kew fungarium from the Kelvinside garden date either from 1899 or from 1989 and represent species that are relatively common and widespread in the British Isles, although Clavaria tenuipes recorded at the earlier date has been confused more recently with $C$. krieglsteineri. It has certainly been found in the glasshouse in the Edinburgh Botanic Gardens growing on peaty potting compost. The moor club (C. argillacea) has also been found in the temperate glasshouses in Edinburgh amongst ericaceous propagation materials. It is widespread in the British Isles, growing in heathland and moorland, although the species has been separated into two entities on the basis of molecular data. It is probably more common in Scotland than further south. It is associated with members of the Ericaceae with which it has been demonstrated as having a mycorrhizal association. A third species, white spindles (C. fragilis), is widespread and common in Britain in fields and pastures, even growing along grassy verges to trails. After 100 years C. argillacea was again found in the Kelvinside garden along with four collections of the equally common yellow club (Clavulinopsis helvola, recorded as C. inaequalis var. helvola) and having the same ecology. Also recorded from the Kelvinside garden is Ramariopsis (formerly Clavaria) kunzei, which is occasionally collected in garden borders and at woodland margins. There is a record of the little known and rare fairy club "Clavaria (now Clavulinopsis) candida". However, from parallels with other fungi found in botanic gardens there is every likelihood that this represents the common and widespread pointed club (C. acuta), which often grows amongst potted plants, in garden borders and also in open woodland. There is also material of the ascomycetous Trichoglossum walteri from 1889 in the Kew fungarium associated with the fairy club collections; being an earth-tongue, this bears an uncanny resemblance to a club fungus. T. walteri apparently requires a similar nutritional environment and was re-determined by R.W.G. Dennis. It is very uncommon and possibly introduced, as it is most frequently found in urban situations in lawns and grassland, whilst the native habitat in the U.K. is unknown. Paterson (1876) had earlier recorded the upright coral Ramaria (as Clavaria) stricta, a fungus which is not uncommon, cropping up in garden borders on wood-chips or woody debris. It is the only British clavarioid fungus that is lignicolous.

In the autumn of 1980 the British Mycological Society visited the Glasgow area and generated some records for the Kelvinside garden (Moodie, 1981). Whereas several sites were visited outside Glasgow centre during that meeting, only a "snatch-like" visit was made to the garden. Most of the fungi found were agarics associated with trees (ectomycorrhizal) amongst which the grey veiled amanita (Amanita porphyria) was a surprise. This species is "rare to not common" according to Legon \& Henrici (2005) and is often confused with the very variable $A$. excelsa. The latter has been found on later visits to the Kelvinside garden. A. porphyria is found in sandy, often rather acidic, pine woodland or Calluna heaths, although occasionally it can be associated with oak.

At a field meeting in 2014, 37 species were recorded, with many new additions to the list of fungi previously recorded in the Garden. The list can be found at gnhs.org.uk/biodiversity/GBG_splist.pdf. Most species were expected, but of particular interest were the earpick fungus (Auriscalpium vulgare) on a conifer cone, pinecone cap (Strobilurus tenacellus), and the holly 
parachute (Marasmius hudsonii) on a cast holly leaf. Also found were the fragile Delicatula integrella, Hemimycena cucculata and Conocybe vestita, all of which are frequently overlooked on a general foray.

Grassland fungi were found in the garden in 2016, including the parrot mushroom (Gliophorus (formerly Hygrocybe) psittacinus) and butter mushroom (Hygrocybe pratensis), both widespread species of grasslands and lawns in Scotland, the latter being recorded also in 1980. The common and widespread orange mosscap (Rickenella fibula), found in both grassy and wooded areas, was also only found in 1980, as was the stump puffball (Lycoperdon pyriforme), the only U.K. puffball growing on woody substrates, and root rot polypore (Heterobasidion annosum), the scourge of the arboriculturist, as it is a very effective parasite of a whole range of woody plants. The pale brittlestem (Psathyrella candolleana) has been found in the Kelvinside (and Sandyford) gardens, but this is a widespread and variable species found in shrubberies and disturbed woods and is generally associated with woody debris; it would be expected in a garden setting. Also found in 2016 were the geranium brittlegill (Russula fellea), Lactarius fluens, a very close relative of the beech milkcap (L. blennius) and like it confined to beech, and the purple brittlegill ( $R$. atropurpurea), which grows with oak. The beechwood sickener (R. nobilis), also found in 2016 and probably better known as $R$. mairei, grows with beech, whilst the ochre brittlegill ( $R$. ochroleuca) can be found with a whole range of species from late spring until the first frosts. In contrast, the birch milkcap (Lactarius tabidus) grows in frondose woods but generally with birches (Betula spp.). Also found in the garden was the soap-smelling Hebeloma pallidoluctuosum (related to, yet quite distinct from, the sweet-scented sweet poison-pie (H. sacchariolens) and the leopard spotted earth ball (Scleroderma areolatum), an ectomycorrhizal species often found on borders in gardens and parks. The 2016 collecting opportunity was a National Fungus Day celebration organised by the Clyde \& Argyll Fungus group under the umbrella of the British Mycological Society. In a short space of time 38 species of larger fungi were collected, including both saprotrophic and some ectomycorrhizal species. All the ectomycorrhizal species indicated above are fairly widespread if not very common throughout Scotland. Of particular interest was Xerocomus cisalpinus which, although only recently described as new to science, is widespread in disturbed woodland-margins and garden borders. It is closely related to the red cracking bolete (X. chrysenteron), with which it has been surely confused in the past. Amongst the non-mycorrhizal larger fungi found was the shaggy scalycap (Pholiota squarrosa), growing at the base of an old specimen tree but hardly a threat, and the pale brittlecap mentioned earlier was also on wood. Amongst the saprotrophs found was Agaricus dulcidulus, a small true mushroom with an amethyst coloured cap and slightly yellowing stem; it also has small spores and perhaps was least expected. It was also a great pleasure in 2016 to see in a recently tilled area ready for planting a rather impressive, large troop of the stubble rosegill
(Volvariella gloiocephala), a close relative of the paddy straw fungus (Volvariella volvacea), an exotic mushroom served extensively in Chinese restaurants in Glasgow.

\section{MICROFUNGI OF THE SANDYFORD AND KELVINSIDE GARDENS}

There is no doubt Klotzsch collected microfungi, but only one in the Scottish collections has been documented as being from Sandyford (Watling, 2014). The collection is filed under Sphaeria (Depazea) unedonicola and was found on leaves of strawberry tree (Arbutus unedo). It is a name which appears to have been applied to a non-sporulating member of the Sphaeropsidales: Phomeae on this host and is another example of a fungus that was introduced to Glasgow. Hooker (Peebles, pers. comm., 2017) also notes a fungus which must have been an introduction to the Sandyford garden, viz. Taphrina populina on black poplar (Populus nigra), and Paterson amongst his listings for Kelvinside records six microfungi, all on plant remains.

Paterson (1876) records Myxosporium (= Gloeosporium) orbiculare, a fungus attacking cultivated cucurbits, coral spot or pea stick fungus Nectria cinnabarina (recently found again in the Kelvinside garden) collected under the name Nectria ochracea; and Stictis phacidioides, which is now placed in Marthamyces, a close relative of the tar spot fungus noted below. Paterson (1876) recorded microfungi now placed in the genera Apiosporopsis, Coniothyrium, Coryneum, Diaporthe and Pestalotiopsis, the last being a foliar disease which may have been introduced to Kelvinside from foreign parts. A fungus on podocarps (Podocarpus spp.) found in the Kelvinside garden in 1933 proved to be a species new to science, viz. Pestalotiopsis (as Pestalotia) podocarpi Dennis, 1934 (Dennis, 1934). This has apparently not been seen since.

Other microfungi recorded from Kelvinside include mildews (Erysiphaceae), two species on Rhododendron spp. and one on hogweed (Heracleum sphondylium), a wayside plant. The latter was collected in 1980. Two rust-fungi listed by Paterson (1876), viz. Xenodochus carbonarius on great burnet (Sanguisorba officinalis) and Endophyllum sempervivi on houseleek (Sempervivum spp.), are both rather significant records, although the latter is known from elsewhere in Scotland, attacking plants in ornamental succulent collections. Four fungi specifically apply to the Kelvinside garden in Boyd's account (1901). The little known cup-fungus Lachnum (as Dasyscypha) lanariceps and Colletotrichum coccodes (as Gloeosporium elasticum) on dead leaves of rubber fig (Ficus elastica) were then the only British records, both attributed to Boyd. L. lanariceps is known from Australia, Java, the Philippines and Ceylon, where it is said to grow exclusively on the tree fern Cyathea walkerae: it must have been introduced! The other two are diseases: Graphiola phoenicis of palms, apparently introduced into many botanic gardens, and the native Puccinia soldanellae. Some microfungi form rather obvious fruiting bodies, unlike the usual spots and specks. One 
such fungus is dead man's fingers (Xylaria polymorpha) found in the Kelvinside garden by a member of the public. As the common name suggests, the fruiting bodies form darkened finger-like structures like mummified human digits. It might be expected on any woody substrate. Another larger ascomycete recorded from the garden is the elf cup Peziza cerea, which might have been expected, as it grows commonly in outhouses on old sacking etc. and even in dwellings.

Polycephalomyces tomentosa, recorded as Blistum ovalisporum in Moodie (1981), is a distant relative of the vegetable caterpillar fungi (Ophiocordycipitaceae) but, instead of attacking adult insects or their larvae, it probably parasitises a wide selection of slime moulds myxomycetes, on which it fruits. More widespread are several parasites with specific hosts. During the 2014 foray several were recorded including four rust-fungi: Uromyces dactylidis on wood meadow-grass (Poa nemoralis), Puccinia aegopodii on bishop weed (Aegopodium podagraria), P. sessilis on Phalaris sp. (another grass), and P. caricina var. ribesii-pendula on sedges. Red spots on Rumex caused by Ramularia rubella, also a specialised parasite, were evident in the shrubbery. The tar spot Rhytisma acerinum on sycamore leaves (Acer pseudoplatanus) was in evidence in 2016, an indication of the improvement in air quality since the previous industrial era. The pin-head shiny fungus Coleroa robertiani on herb robert (Geranium robertianum) and Trochila craterium forming whitish spots with small black specks in the centre of ivy leaves (Hedera spp.) were both found in 2016, as might be expected. The ergot fungus Claviceps purpurea was present on the inflorescences of wood meadow-grass, replacing the ovules with black resting structures (sclerotia). Perhaps the microfungus causing the most visible impact in the Kelvinside garden was the mould Cristulariella depraedens on fading attached leaves of sycamore.

The River Kelvin runs beside the present day Kelvinside garden. Galloway \& Elliott (1987) conducted a survey of aquatic fungi in the Kelvin and the Allander Water from October 1986 until January 1987. There is little doubt that, even if not recorded from a site in the garden, data from the Kelvin indicate species potentially present in the garden, as their propagules are dispersed by water currents. A total of 18 different species was recorded from the two Kelvin sites, with Flagellospora curvula and Lemonniera aquatica being the commonest. Conidia of Articulospora tetracladia and Clavariopsis aquatica occurred in good numbers but with greater variation than amongst Allander Water samples. Perhaps this reflects a heavy pollution load in the Kelvin in 1986-7.

An unfortunate recent record made by a member of staff at the Kelvinside garden is of Phytophthora ramorum (sudden oak death). Formerly considered to be a fungus but now placed in an unrelated group (Chromista: Peronosporaceae), this will have been introduced into the garden, as has occurred elsewhere in Scotland and the U.K. It is a root parasite and the motile spores allow it to spread from site to site. With a wide range of hosts both arborescent and herbaceous it can become a scourge. Disinfectant control is necessary.

\section{CONCLUSIONS}

If the species found in 2016 are anything to go by, taxa labelled "common" by Klotzsch but unlocated, such as the widespread ectomycorrhizal deceiver (Laccaria laccata), certainly will be present at Kelvinside. There is no doubt that the changing management of any garden introduces new species even today. It must be realised that fungi can be hidden from view for months of the year, living in the soil etc. and only fruiting ephemerally when favourable conditions prevail; it is only then that their presence can be detected. Molecular techniques are now becoming available which will detect their presence without the need to identify a fruiting body. Some fungi may remain in the soil out of sight for many years before making an appearance.

All species recorded from the Sandyford and Kelvinside gardens are listed in the Appendix to this paper. Some very interesting and noteworthy fungi have been found in the two Glasgow gardens, but there is no doubt that a concerted effort would find many more species. Changes have been seen between the early Klotzsch collections and the present day, mainly due to major changes in the built environment and industrial activities in the city, with some previously rare species having been lost from Glasgow (Watling, 2015). Nevertheless, important mycological contributions have been achieved. There is no doubt that a list of the more common species could easily be amassed to add to the records already available by a few short forays around the grounds and may result even in some surprises, especially if those found in the warm humid conditions of the Kibble Palace are examined in detail! The recent finding by Luka Large of the holly speckle (Trochila ilicina), which causes small shiny black pustules on dead holly leaves, shows there is much to do!

\section{ACKNOWLEDGEMENTS}

I am deeply grateful to Dick Peebles, who read a draft of this account and supplied more expansive information on key players and some of the record details, Richard Weddle who also read a very early draft, Brian Douglas for information concerning material in Royal Botanic Gardens, Kew, and the staff of the Library of the Royal Botanic Gardens, Edinburgh for their help in tracing obscure publications.

\section{REFERENCES}

Anon. (1877). Exotic fungi in Scotland. Grevillea 5, 112. https://doi.org/10.1093/nq/s5-VII.164.126c

Anon. (1928). Handbook: British Association for the Advancement of Science. Glasgow meeting. Blackie \& Son, Glasgow.

Bolton, J. (1788). An History of Fungusses, Growing about Halifax. Vol. 1. Halifax.

https://doi.org/10.5962/bhl.title.5394 
Boney, A.D. (1986). The history of the Glasgow University Physic Garden. Transactions of the Botanical Society of Edinburgh 45 (1), 43-62. https://doi.org/10.1080/03746608608685404

Bower, F.O. (1901). History of botany in Glasgow. In: Scott Elliot, G.F., Laurie, M. \& Murdoch, J.B. (Editors). Fauna, Flora and Geology of the Clyde Area, pp. 3-5. British Association for the Advancement of Science, Glasgow.

Boyd, D.A. (1901). Fungi (microscopic). In: Scott Elliot, G.F., Laurie, M. \& Murdoch, J.B. (Editors). Fauna, Flora and Geology of the Clyde Area, pp. 6177. British Association for the Advancement of Science, Glasgow.

Boyd, D.A. (1928). Physical features of the Clyde District relating to the occurrence of fungi. In: Patton, D. (Editor). Handbook: British Association for the Advancement of Science, pp. 313-317. Burlington House, London.

Dennis, R.W.G. (1934). Pestalotia podocarpi Dennis, nov. sp. Phytopathology 24, 1028.

Dickson, J. (1785-1801). Fasciculus Plantarum Cryptogamicarum Britanniae. London.

Galloway, Y. \& Elliott, C.G. (1987). Hyphomycetes in the River Kelvin. Transactions of the Botanical Society of Edinburgh 45(2), 141-148. https://doi.org/10.1080/03746608708685424

Greville, R.K. (1823-28). Scottish Cryptogamic Flora. Vols. 1-6. MacLachlan \& Stewart, Edinburgh.

Grove, W.B. (1935-37). British Stem and Leaf Fungi. Vols. 1-2. Cambridge University Press, Cambridge.

Hennedy, R. (1878). The Clydesdale Flora. Hugh Hopkins, Glasgow.

Hooker, W.J. (1836). The English Flora of Sir James Edward Smith. Class XXIV. Cryptogamia. Vol. V(or Vol. II of Dr. Hooker's British Flora). Part II. Comprising the Fungi; by the Rev. M.J. Berkeley. Longman et al., London.

Hopkirk, T. (1813). Flora Glottiana. V. Fungi. pp. 154166. Constable, Edinburgh.

Johnstone, R.B. (1931). Obituary: Daniel Alexander Boyd. The Glasgow Naturalist 9, 60-62.

Johnstone, R.H. (1946). Some Clydesdale records of fungi. The Glasgow Naturalist 15, 59-62.

Lee, J.R. (1933). The Flora of the Clyde Area. Smith \& Son, Glasgow.

Legon, N.W. \& Henrici, A. (2005). Checklist of British and Irish Basidiomycota. Royal Botanic Gardens Kew, Richmond.

Lightfoot, J. (1777). Flora Scotica. Vols. 1-2. White, London.

Moodie, W.T. (1981). Foray reports: Autumn foray, Glasgow. Bulletin of the British Mycological Society $15,87-96$. https://doi.org/10.1016/S0007-1528(81)80010-7

Paterson, R. H. (1876). Fungi. In: Stirton, J. (Editor). On the Fauna \& Flora of the West of Scotland. Handbook: British Association for the Advancement of Science. Glasgow meeting. Blackie \& Son, Glasgow.

Patton, D. (1928). General Handbook. British Association for the Advancement of Science, Glasgow meeting 1928. Blackie \& Son, Glasgow.
Persoon, C.H. (1797). Tentamen Dispositionis Methodicae Fungorum. P.D.Wolf, Leipzig.

Ramsbottom, J. (1963). History of Scottish mycology. Transactions of the British Mycological Society 46, 161-178. https://doi.org/10.1016/S0007-1536(63)80072-8

Stevenson, J. (1879). Mycologia Scotica or the Fungi of Scotland. Cryptogamic Society of Scotland, Edinburgh.

Stewart, W. (1901). Hymenomycetes and gastromycetes. In: Scott Elliot, G.F., Laurie, M. \& Murdoch, J.B. (Editors). Fauna, Flora and Geology of the Clyde Area, pp. 78-92. British Association for the Advancement of Science, Glasgow.

Ure, D.M. (1792). The History of Rutherglen and East Kilbride. David Niven, Glasgow.

Watling, R. (1986). 150 years of paddock stools: a history of agaric ecology and floristics in Scotland. Transactions of the Botanical Society of Edinburgh 45(1), 1-42. https://doi.org/10.1080/03746608608685403

Watling, R. (2014). Johan Frederick Klotzsch's pre1850 material in the Glasgow Museums collections and its significance. The Glasgow Naturalist 26(1), 93-100.

Watling, R. (2015). Links between the old and the new. Journal of Fungal Research 13(4), 205-211.

Watling, R. (2016). J.F. Klotzsch: his Scottish legacy. The Glasgow Naturalist 26(2), 53-60.

Withering, W. (1792). A Botanical Arrangement of British Plants. (2nd edition). Vol. 3. M. Swinney, London. 


\section{APPENDIX}

\section{Non-lichenised fungi recorded from the Sandyford and Kelvinside gardens}

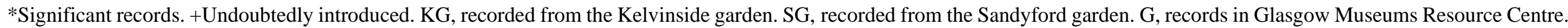

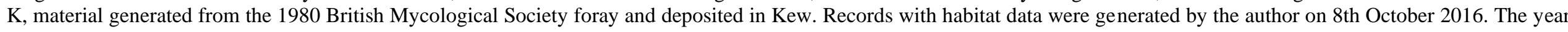
when a record was made is shown for some species.

\section{Basidiomycota}

\section{Agaricales}

Agaricaceae

Agaricus dulcidulus Schulzer - KG, amongst grass.

Echinoderma asperum (Pers.) Bon (as Agaricus mariae Klotzsch) - KG (1876); SG.

*Lepiota (as Agaricus) clypeolaria (Bull.) Kummer - KG (1876).

*Leucoagaricus (as Agaricus) meleagris (Sow.) Singer - KG (1876).

*Leucocoprinus (as Agaricus) cepistipes (Sow.) Pat. - KG (1876).

*Melanophyllum haematospermum (Bull.) Kreisel (as Agaricus hookeri Klotzsch) - KG (1905); SG.

Lycoperdaceae

Lycoperdon pyriforme Schaeff. - KG; G; K

Vascellum pratense (Pers.) Kreisel - KG, in grass.

Amanitaceae

Amanita excelsa (Fr.) Bertill. - KG, margin of lawn; K.

Amanita muscaria (L.) Lam. - KG; K.

Amanita porphyria A. \& S. - KG; K.

Amanita rubescens Pers. - KG, under frondose trees; K.

Bolbitiaceae

Bolbitius titubans (Bull.) Fr. - KG; G.

Conocybe vestita (Fr.) Kühner - KG; G. Note that Agaricus (Galera) confertus Bolton in Paterson (1876) has been assigned to this genus; see below.

Coprinaceae

Coprinellus micaceus (Bull.: Fr.) Vilgalys et al. - KG; G

Coprinopsis lagopus (Fr.: Fr.) Redhead et al. - KG; G.

Lacrymaria lacrymabunda (Bull.) Pat. (as Agaricus tabularis Peck) - KG, edge of shrubbery; SG.

Parasola plicatillis (Curtis: Fr.) Redhead et al. - KG, in grass.

Psathyrella candolleanum (Fr.) Maire - KG; SG; G; K.

Psathyrella gracilis (Fr.) Quél. (= P. corrugis f. gracilis (Pers.) Konrad \& Maubl.) $\mathrm{KG}$, in grass.

Psathyrella sp. - KG. This is identified as "Mycena proliferus Sow." However, the original illustration of M. proliferus by James Bolton (1788: Plate 18) is considered by
Legon \& Henrici (2005) to look very similar to a sterile Psathyrella; sterility is a common phenomenon in some dark-spored agarics, making resemble a paler spored species of mushroom.

Crepidotaceae

Inocybe cincinnata (Fr.) Quél. - KG, under Quercus?

Inocybe geophylla (Sowerby) P. Kumm. - KG, under Fagus and Quercus; K.

Inocybe napipes J.E. Lange, - KG, under Quercus.

Inocybe rimosa (Bull.) P. Kumm. - KG, several sites under various trees.

Entolomataceae

Entoloma (Nolanea) conferendum (Britzelm.) Noordel. - KG, in grass under various trees; G.

Hydnangiaceae

*+Hydnangium carneum Wallr. - KG (1876); SG

Laccaria laccata (Scop.) Cooke - KG, several sites, especially under newly planted trees.

Hygrophoraceae

Gliophorus psittacinus (Schaeff.) Herink - KG; K.

Hygrocybe pratensis (Pers.) Murrill - KG, in grass; K.

Marasmiaceae

*Marasmius hudsonii (Pers.) Fr. - KG; G.

Mycenaceae

Hemimycena (as Mycena) cucculata (Pers.) Singer - KG; G.

Physalacriaceae

Strobilurus tenacellus (Pers.) Singer - KG; G.

Pluteaceae

Volvariella gloiocephala (DC.) Boekhout \& Enderle (as V. speciosa (Fr.) Singer) - KG,

in vegetable garden in newly manured plot.

Schizophyllaceae

+Schizophyllum commune Fr. - KG (1905).

Tricholomataceae

Clitocybe nebularis (Batsch) P. Kummer - KG, in shrubbery.

Delicatula (as Mycena) integrella (Pers.) Fayod - KG; G.

Gymnopus (as Collybia) inodorus (Pat.) Anton. \& Noordeloos - KG; G. 
*Lepista saeva (Fr.) P.D. Orton - KG (1978).

Lepista (as Agaricus) sordida (Schumach.) Singer - KG, (1897).

Melanoleuca cognata (Fr.) Konrad \& Maublanc - KG; G.

Melanoleuca grammopodia (Bull.) Fayod - KG, by side entrance in grass and edge of lawn in main garden.

Melanoleuca strictipes (P. Karst.) Schaeff. - KG, in shrubbery.

\section{Auriculariales}

Auricularia auricula-judae (Bull.) Wettst. - KG; G.

\section{Boletales}

\section{Xerocomaceae}

Boletus cisalpinus Simoni et al. - KG, under Quercus.

Sclerodermataceae

Scleroderma areolatum Ehrenb. - KG, under Quercus.

\section{Cantharellales}

\section{Cantharellaceae}

Cantharellus cibarius Fr. - KG, (1890).

Clavariaceae

Clavaria acuta Sow. (as C. candida certified by M.C. Cooke, but see discussion in text)

- KG (1876).

Clavaria argillacea Pers. - KG (1899, 1980); K

Clavaria fragilis Holmsk. - KG (1899); K.

Clavaria tenuipes Berk. \& Br. - KG (1899); K.

Clavulinopsis helvola (Pers.) Corner - KG; three collections deposited in $\mathrm{K}$.

Ramariopsis kunzei (Fr.) Corner - KG; G.

\section{Cortinariales}

\section{Cortinariaceae}

Collection agreeing in all ways with Cortinarius rigens (Pers.) Fr. - KG, under Quercus.

Hymenogastraceae

Gymnopilus junonius (Fr.) Orton - KG? (1876).

Hebeloma crustuliniforme (Bull.) Quél. - KG, several sites, edge of line of trees; also recorded in 1897 and 1905.

Hebeloma pallidoluctuosum Gröger \& Zschiesch. - KG, under frondose trees amongst grass.

*Hebeloma radicosum (Bull.) Ricken - KG (1876).

*Hymenangium album Klotzsch - KG; SG; K.

*Hymenogaster muticus Berk. \& Br. - KG (1876).

Strophariaceae
Pholiota squarrosa (Oeder) P. Kummer - KG, base of living Salix.

Psilocybe montana (Pers.) P. Kummer - KG; G.

\section{Exobasidiales}

Graphiolaceae

*+Graphiola phoenicis (Moug. ex Fr.) Poit. - KG (1905).

\section{Fistulinales}

Fistulinaceae

Fistulina hepatica (Schaeff.) With. - KG (1876).

\section{Ganodermatales}

Ganodermataceae

Ganoderma australe (Fr.) Pat. - KG; G.

\section{Gomphales}

Geatraceae

Geastrum triplex Jungh. - KG (1905).

Gomphaceae

Ramaria stricta (Pers.) Quél. - KG (1876).

\section{Hymenochaetales}

Hymenochaetaceae

Rickenella fibula (Bull.) Raithelh. - KG; K.

Hyphondontaceae

Lyomyces sambuci (Pers.) Karst. - KG, on fallen woody trash in shrubbery; G.

Schizoporaceae

Schizopora paradoxa (Schrad.) Donk - KG, on fallen branch.

\section{Polyporales}

Coriolaceae

Datronia mollis (Sommerf.) Donk - KG; G.

*+Pycnoporus cinnabarinus (Jacq.) Karst - KG; K.

Trametes versicolor (L.) Pilát - KG; G.

*+Trichaptum biforme (Fr.) Ryvarden - KG; K.

Hyphodermataceae

Hyphoderma praetermissum (P. Karst.) Erikss. \& Strid - KG, on fallen branch.

Hyphoderma (Basidiodendron) radula (Fr.) Donk - KG, on fallen twig.

Polyporaceae

Polyporus tuberaster (Jacq. ex Pers.) Fr. - KG, with blackened swollen base, on buried wood. 


\section{Russulales}

Auriscalpiaceae

Auriscalpium vulgare Gray - KG; G.

Bondartzewiaceae

Heterobasidion annosum (Fr.) Brefeld - KG; K.

Peniophoraceae

Peniophora limitata (Chaillet ex Fr.) Cke. - KG; G.

Peniophora lycii (Pers.) Höhn. \& Litsch. - KG; G.

Russulaceae

Lactarius fluens Boud. - KG, with Fagus; K.

Lactarius tabidus Fr. - KG, in shrubbery under mixed trees.

Russula atropurpurea (Krombh.) Brizelm. - KG, with Quercus.

Russula fellea (Fr.) Fr. - KG, with Fagus; K.

Russula nobilis Velen. - KG, with Fagus.

Russula ochroleuca Fr. - KG, several collections, various trees including Fagus, Quercus and Acer pseudoplatanus; K.

Stereaceae

Stereum hirsutum (Willd.) Pers. - KG, on fallen branch; G.

*+Stereum ostrea (Blume \& Nees) Fr. - KG; K.

Stephanosporaceae

*Stephanospora caroticolor (Berk.) Pat. - KG (1901); K.

\section{Tremellales}

Exidiaceae

Exidia glandulosa (Bull.) Fr. - KG (1905).

\section{Uredinales}

Phragmidiaceae

*Xenodochus carbonarius Schtdl. - KG (1876).

Pucciniaceae

*+Endophyllum sempervivi (A.\& S.) de Bary - KG (1876).

Puccinia aegopodii (Schumach.) Mart. - KG; G.

Puccinia caricina var. ribesii-pendulae (Hassler) Hend. - KG; G.

Puccinia sessilis Schroet. - KG; G.

Puccinia soldanellae (DC.) Fuckel - KG (1905).

Uromyces dactylidis Otth. - KG; G.

\section{Ascomycotina}

\section{Clavicipitales}

Clavicipitaceae

Claviceps purpurea (Fr.) Tul. - KG, on inflorescences probably of Poa nemoralis.
Ophiocordycepitaceae

Polycephalomyces (as Blistum) tomentosus (Schrad.) Seifert - KG; K.

\section{Diaporthales}

Apiosporiopsidaceae

Apiosporopsis (as Sphaeria) carpinea (Fr.) Mariani - KG (1876)

Diaporthaceae

Diaporthe (as Sphaeria) pardalota (Mont.) Nits. ex Fuckel - KG (1876).

Mycosphaerellaceae

Ramularia rubella (Bon.) Nannf. - KG; G.

Pseudovalsaceae

Coryneum microstictum Berk \& Br. - KG (1876)

\section{Dothideales}

Dothideacea

Dothidea sambuci (Pers.) Fr. - KG (1928).

\section{Erysiphales}

Erysiphaceae

Erysiphe azaleae (U. Braun) U. Braun \& S. Takam. - KG, on undersurface of living attached leaves of elepidote (large leaved) Rhododendron hybrids.

Erysiphe heraclei DC. - KG; K.

Oidium (type of spore) probably of Phyllactinia guttata (Wallr.) Lév. - KG, smothering living leaves of reddening shoots of a Rhododendron cultivar.

\section{Geoglossales}

Geoglossaceae

*Trichoglossum walteri (Berk.) Durand - KG (1899); K.

\section{Helotiales}

Dermataceae

*+Colletotrichum coccodes (Wallr.) Hughes (as Gloeosporium elasticae Cooke \& Massee) - KG (1904)

*Gloeosporium orbiculare (Berk.) Berk. - KG (1904).

Hormotheca robertiani (Fr.) Höhn. - KG, on living Geranium robertianum leaves in shrubbery.

Trochila craterium (DC.) Fr. - KG, forming whitish areas on fading Hedera leaves.

T. ilicina (Nees ex Fr.) Greenh. \& Morgan-Jones - KG, on cast leaves of Ilex.

Hyaloscyphaceae

*+ Lachnum lanariceps (Cooke \& Phillips) Spooner - KG, collected by W. Stewart.

Phacidiaceae 
Phacidium multivalve (DC.) Kunz. - KG; G.

Sclerotiniaceae

Cristulariella depraedens (Cooke) Höhn. - KG, on attached fading leaves of Acer pseudoplatanus.

\section{Hypocreales}

\section{Nectriaceae}

Nectria cinnabarina (Tode) Fr. - KG (1876).

\section{Pezizales}

Pezizaceae

Aleuria aurantia (Pers.) Fuckel - KG, side of path.

Peziza cerea Sow. - KG (1876).

\section{Pleosporales}

Pleosporaceae

Macrosporium macrosporum (Zimm.) Nishikado \& Oshima (as Alternaria macrospora Zimm.) - KG (1928).

\section{Rhytismatales}

\section{Rhytismataceae}

*Marthamyces (as Stictis) phacidioides (Fr.) Minter - KG (1905).

Rhytisma acerinum (Pers.) Fr. - KG, on attached and fallen leaves of Acer pseudoplatanus; $\mathrm{G}$.

\section{Taphrinales}

\section{Taphrinaceae}

Taphrina populina (Fr.) Fr. - SG (1825), recorded by Hooker (see main text).

\section{Xylariales}

Amphisphaeriaceae

+Pestalotiopsis (as Pestalotia) guepinii (Desm.) Steyaert. - KG (1876).

+*Pestalotiopsis (as Pestalotia) podocarpi (Dennis) X.A. Sun \& Q.X. Ge - KG (1933)

Diatrypaceae

Diatrype stigma (Hoffm.) Fr. - KG (1905).

Xylariaceae

Hypoxylon fragiforme (Pers.) Kickx. - KG; G.

Xylaria carpophila (Pers.) Fr. - KG (1905).

Xylaria hypoxylon (L.) Grev. - KG; G.

Xylaria polymorpha (Pers.) Grev. - KG (1876).

Ustulina vulgaris Tul. \& Tul. - KG; G.

\section{Unidentifiable}

*Sphaeria (Depazea) unedonicola Klotzsch - SG; unsporulating and therefore unidentifiable; vide Grove (1935-37) and main text.

\section{Chromista}

\section{Perenosporaceae}

Phytophthora ramorum Werres et al. - KG, isolated from root fragments. 